\title{
Rotator cuff Disease: Aspects and Implications
}

\author{
Afección del Manguito Rotador: Aspectos e Implicancias
}

Josiane Schadeck de Almeida; Guaracy Carvalho Filho \& Neuseli Marino Lamari

DE ALMEIDA, J. S.; CARVALHO FILHO, G. \& LAMARI, N. M. Rotator cuff disease: aspects and implications. Int. J. Morphol., 23(4):381-385, 2005.

SUMMARY: The objetive this study was analyze the characteristics of the rotator cuff disease carrying and its implications by the lesion evolutional stage. 112 patients with initial diagnosis of rotator cuff disease were interviewed, most of them women, average age of 51 years, right side more injured, with evidence to be the most damaged $(\mathrm{p}=0,00)$ and with a lot incapacity to move the upper limbs $(\mathrm{p}<0,05)$. The most found pathology stage was the partial rupture of supraspinatus tendon, 26,16 months of attendance and without association with pathology stages. Most of patients were treated with physiotherapy and just $19 \%$ of them were submitted to the surgery procedure. It has shown that this pathology implies in lots functional damages, affects social and work standard with high incapacities on upper limbs even after treatment.

KEY WORDS: Shoulder impingement syndrome; Physical therapy; Rotator cuff.

\section{INTRODUCTION}

In the latest years, a lot has been researched about the anatomical-pathological mechanism of the rotator cuff disease (Greve et al.,1992; Bertoncello et al., 1999), because it constitutes the most common cause of painful symptoms or functional limitation of the shoulder (Giordano et al., 2000; Guimarães, 1995; Carpenter et al., 1998).

The rotator cuff complex formed by the tendon of supraspinatus, infraspinatus, subscapularis and teres minor muscles (Gagliardi \& Lissi, 2002; Hamil et al.,1999) is essential during the arms common movements, demands from these structures a perfect integrity and anatomic configuration for the correct functionality (Plancher et al., 1995; Teixeira-Salmela \& Monteiro,2001).

Factors as inadequate posture of upper limbs (Sakata \& Issey,2003), repetitive (Carpenter et al.; Filho \& Barreto, 1998), biologic aging, lack of vascularity related to the tendon and traumatism are quoted as the main causes of rotator cuff disease (Lin et al., 2001; Novak \& Mackinnon, 1997; Ludewig \& Borstard, 2003; Pope et al., 2001). The structures more attacked are supraspinatus tendon, long head of brachial biceps muscle and sac synovial subacromial (Greve et al., 1992).
The theory of impact described by Neer (1983), defined as the supraspinatus tendon compression against the coracoacromial arc when upper limb is raised, has a strait relation with the pain in the shoulder (Neer; Whiting \& Zernicke, 2001). The presence of an hypovascular area benefits the evolution of a lesion in this part (Rockwood \& Matsen III, 2002) joining with alterations in elasticity, flexibility and mechanical capacity (Greve et al., 1992).

Abduction and repeated lateral rotation of the arms above transcromial line cause inflammatory procedures and, sometimes, caused by rotator cuff rupture of acromial impact against supraspinatus tendon, which preclude movements with the arm and prejudice its activities (Sporrong et al., 1999; Stenlund et al., 2002).

Pathology spectrum of rotator cuff disease is wide and goes from a stage of tendonitis until a total rotator cuff tears (Ragasson \& Stabille, 2001). It is justified by the interest in understand the lesions on the shoulder biomechanic and the pathology process to help the characterization of clinical stage in a more effective way (Fuentes, 2003). 
It has looked for in this study exclude from the ranks the patient with rotator cuff disease since the lesion evolutional stage as well as to demonstrate its implications on these patients' lives.

\section{METHOD AND METHOD}

It is a transversal study, 112 patients were interviewed with initial diagnosis of rotator cuff disease made between April and November of 2004, in the Ambulatory Service of Superior Member of Orthopedics and Traumatology Department in a public hospital of São José do Rio Preto Medicine School, approved by the Ethics Committee in Research from the same institution, register $N^{\circ} 1941 / 2004$.

All the patients did the ultrasound and/or magnetic resonance to confirm the diagnosis. They were factors of exclusion, people with history of surgeries or preceding fractures on the shoulder, articular instabilities and affection in a tendon that weren't of the supraspinatus muscle.

$\mathrm{He} / \mathrm{she}$ acts, pathology evolution, team of medical attendance, proposed treatment and present incapacities were analyzed.

The informations were kept on Microsoftâ Excelâ and submitted to statistical descriptive analysis. The results analyses were made by test qui-square, Mood and " $t$ " of Student. The significance level was $5 \%$.

\section{RESULTS}

The descriptive analysis has shown that between the 112 patients, $75(67 \%)$ were from the female sex and 37 (33\%) were from the male sex, whose average age was of 51 years with a pattern deviation of 9 years and median value of 52 years. The most found pathology stage (45\%) was the partial rupture of the supraspinatus tendon (50), tendonitis in 46 patients $(41 \%)$ and total rupture of the same tendon in 16 patients $(14 \%)$. The right side was more attacked, represented by 78 (69\%) of the patients, followed by the left side with $30(27 \%)$ and with 4 (4\%) injured both limbs.

Between the analyzed patients, female sex had more frequency in diagnosis partial rotator cuff tears of supraspinatus represented by $37(74 \%)$ women and the male sex with $13(26 \%)$. Similar results were verified in relation to the supraspinatus tendonitis with $65 \%$ (30) in women and $35 \%$ (16) in male. The total rotator cuff tears of supraspinatus tendon had the same percentage in both sexs, with $50 \%$ represented by 8 patients. By the statistics analysis, there was not association evidence between sex and diagnosis $(\mathrm{p}=0,20)$.

Considering the time of medical attendance since the date of the first consultation in the orthopedics ambulatory until the interview date of this study, the averagefound was 26,16 months with pattern deviation of 20 months.

The averages of medical attendance time according to the pathology stage were of 27 months for partial rupture of supraspinatus tendon with pattern deviation of 21 months, 26 months for total tears with pattern deviation of 16 months and 25 for supraspinatus tendonitis with pattern deviation of 20 months. The median values found were: 23 months to patients with partial tears of supraspinatus tendon, 26 months to those with total tears of the same and 20 months to those with supraspinatus tendonitis. According to the Mood test to median values, there was not evidence of difference between the median values of the medical attendance period by diagnosis $(\mathrm{p}=0,70)$.

There was not significance of difference between the period medias of the medical attendance according to the sex.

It has observed that most, in other words, 103 (92\%) of the patients were orientated by the orthopedist doctor to the physiotherapeutic valuation. From these, 93 (83\%) have already done physiotherapy treatment in a period of time of 2 to 4 years, followed by 26 (28\%) in more than 49 months. Although, there was not association evidence between time of physiotherapy treatment with evolution of the pathology spectrum $(\mathrm{p}=0,90)$.

According to the patients report, the physiotherapy procedures more used were the exercise with $81 \%$ (78) and the electrotherapy with $68 \%$ (63). Other resources were also quoted as cryotherapy (15\%) and use of massage (5\%).

It was verified that $21(19 \%)$ were submitted to surgery treatment and almost its totality (95\%), representing by 20 patients, appealed to physiotherapic treatment after the surgery procedure.

From all samples, 88 (79\%) patients had difficulty to perform external rotation with limb elevation (movement to comb the hair); 93 (83\%) had difficulty to perform interior rotation (movement to touch the back pocket); 106 $(95 \%)$ of them presented difficulty to raise the upper limb by the front of the body, making the major tuberosity get 
in touch with the coracoacromial arc (scratch the back). Between the 75 women studied, 70 (93\%) had difficulty to perform the movement of interior rotation with shoulder abduction (to put the bra). According exact test to a proportion, there was evidence that most had difficulty to perform all the quoted movements (value-p<0,05).

\section{DISCUSSION}

Rotator cuff disease is one of the occupational health problems more frequent on the orthopedics ambulatory (Carpenter et al.; Leclear et al., 2004) with high functional damages to its carrying.

Between the patients interviewed, most was female sex, justified to be related more to the kind of activity than to the sex, since women perform different tasks from the ones performed by the men, plus the domestic activities that make difficult the body recovery (Sakata \& Issey; Walsh et al., 2004).

In relation to the patients age, the literature is corroborated with the discoveries found in this study, showing that the patients incidence with rotator cuff disease increase with the age, mainly in people over 50 years (Rockwood \& Matsen, 2002; Gagliardi \& Lissi, 2002). The aging can be an isolated factor to the pathology appearance (Santos \& Filho, 1998). Nevertheless, the disease can be said as a normal degenerative attrition, not necessarily pain causative and shoulder incapacity (Tempelhof et al., 1999).

The rotator lesions are initiated with more frequency in profundity and extend to the surface until become thickness totality defect (Rockwood \& Matsen), results also found in this study.

It has occurred the lesion occurrence in the right side with more frequency is, that is, referred in another's scientific studies. This study suggests relation between dominant limb and lesion side. However, there is a study appointing that there was not predominance of alteration to the radiography in dominant upper limb (Santos \& Filho, 1998).

The interpretation of the medical attendance period is also corroborated by the authors (Greve et al., 1991; Rockwood \& Matsen), showing to be around 25 months. The conservative treatment has shown off important to the pathology rehabilitational process. Nevertheless, it is necessary to identify specific methods, having in mind the divergences that takes to failure or treatment delay.
Discussing techniques of physiotherapic treatment, Souza (1994) believes that modalities as cryotherapy, electrotherapy and exercise can have great values on shoulder lesions treatment, in other words, the physiotherapic treatment relieve the pain, decrease the functional deficiency, rehabilitating the patient (Cailliet, 2000), as it was showed in another studies (Lech et al., 2000; Giordano et al.).

Guimarães points out that the conservative treatment has changed between less than $33 \%$ and more than $90 \%$ of good and excellent results. However, there is variation of these results, due to the sample age and the results interpretation.

Incapability of trivial movements of the upper limbs were discussed by the authors (Geert, 2000; Crusher, 2000), emphasizing great social and work impact in these patients lives, seeing that the most present functional damage on the arms movement (Filho \& Barreto; Rockwood \& Matsen), due to pain and the muscular weakness.

Biomechanicly, the front deltoid is very active on frontal flexion and medium deltoid in the abduction; according to the deltoid strength is directed to upward in the presence of a weak rotator mechanism, the contraction cause an upper dislocation of the humeral head, so that it compresses the rotator cuff remainder in oppose to the coracoacromial arc, increasing the impact process (Rockwood \& Matsen). The activity above the head for an extended period and the associated strength created by the deltoid in the direction of the acromion is, therefore, a contributing factor (Rockwood \& Matsen), justifying the reason of the difficulty on the interior rotation of the movements, elevation of the upper limbs, interior rotation with shoulder abduction (Ludewig \& Borstad), also results found in this study.

The factors involved are evident in the genesis of the rotator cuff disease and its implications. For the patient, in general, the capacity to raise the upper limb actively means functional recovery satisfactory, independent of the grade of amplitude reached. In this way, to return the functionality of the patient's arm is the main goal on the mechanism of the treatment.

In the analysis of this casuistry, it could be found out that the attendance time is large, besides the presence of high incapacities in the trivial movements realization like to get dressed up, which shows that this pathology is a deficiency that implies incapacity and disadvantage social, even after the treatment. 
DE ALMEIDA, J. S.; CARVALHO FILHO, G. \& LAMARI, N. M. Afección del manguito rotador: Aspectos e implicancias Int. J. Morphol., 23(4):381-385, 2005.

RESUMEN: El objetivo del estudio fue analizar las características de los portadores de la afección del manguito rotador y sus implicancias por el cuadro de la lesión. Fueron entrevistadas 112 personas, con diagnóstico inicial de afección del manguito rotador, la mayoría compuesta por mujeres de alrededor de 51 años, siendo el lado derecho más afectado, con evidencia de ser el más perjudicado $(\mathrm{p}=0,00)$ y con gran incapacidad de mover los miembros superiores $(\mathrm{p}<0,05)$. La patología más frecuente fue la ruptura parcial del tendón del músculo supraespinal, con tratamiento de 26,16 meses y sin asociación con los estados de la patología. La mayoría de los casos fueron tratados con fisioterapia, y sólo el 19\% fue sometido a procedimiento quirúrgico. Se verificó que esta patología provoca grandes perjuicios funcionales, afectando tanto el ámbito social como laboral, produciendo altas incapacidades en los miembros superiores, aún después del tratamiento.

PALABRAS CLAVE: Síndrome de pinzamiento del hombro ; Terapia física; Manguito de los músculos rotadores.

\section{REFERENCES}

Bertoncello, D.; Almeida, A.; Alem, M. E. R.; Walsh, I. A. P. \& Coury, H. J. C. G. Importância da intervenção preventiva da fisioterapia na readequação ergonômica e análise biomecânica de um posto de trabalho. Fisiot. em Mov., 12:89-6, 1999.

Cailliet, R. Dor no ombro. 3. ed. Porto Alegre-RS, Artes Médicas Sul, 2000.

Carpenter, J. E.; Flanagan, C. L.; Thomopoulus, S.; Yian, E. H. \& Soslowsky, L. J. The effects of overuse combined with intrinsec or extrinsec alterations in an animal model of rotator cuff tendonosis. Am. J. Sports Med., 26:801-7, 1998.

Crusher, R. H. Rotator cuff injuries. Accid. Emerg. Nurs., 8:129-33, 2000.

Couto, H. A.; Nicoletti, S. J. \& Lech, O. Como gerenciar a questão das L. E. R. /D. O. R. T. Belo Horizonte-MG, Ergo, 1998.

Filho, S. B. S. \& Barreto, S. M. Algumas considerações metodológicas sobre os estudos epidemiológicos das lesões por esforços repetitivos(LER). Cad. Saúde Públ., 14(3):555-63,1998.

Fuentes, J. C. H. Metodo strain index: aplicado para evaluar trabajos com riesgo de desarrollar trastornos dolorosos de extremidad superior distal. Bol. Cient. Asoc. Chil. Segur., 5:4-7, 2003.

Gagliardi, S. A.; Lissi, M. A. S. Hombro doloroso. Reumatol., 18(4):169-79,2002.

Geert, J. M. G.; Leffers, P. \& Bouter, L. M. Shoulder disability questionnaire design and responsiveness of a functional status measure. J. Clin. Epidemiol., 53:2938,2000 .

Giordano, M.; Giordano, V.; Giordano, L. H. B. \& Giordano, J. N. Tratamento conservador da síndrome do impacto subacromial: estudo em 21 pacientes. Act. Fisiatr., 7:139, 2000 .

Greve, J. M. D.; Filho, A. A. F.; Filho, A. Z. \& Neto, R. B. \& Yoshinari, N. H. Síndrome do impacto-anatomia e biomecânica do ombro e correlações clínicas com a síndrome do impacto. Rev. Bras. Reumatol., 32: 89-4,1992.

Greve, J. M. D.; Rossi, J. D. B. M.; Cossermelli, W. \& Filho, A. A. F. Reabilitação funcional das lesões tendinosas degenerativas do ombro. Rev. Hosp. Clín. Fac. Méd. S.Paulo., 46:78-1, 1991.

Guimarães, M. V. Avaliação do tratamento conservador do pinçamento subacromial e das lesões do manguito rotador. Rev. Bras. Ortop., 30(9):645-8, 1995.

Hamil, J. \& Knutzen, K. M. Bases biomecânicas do movimento humano. São Paulo-SP, Manole, 1999.

Lech, O.; Neto, C. V. \& Severo, A. Tratamento conservador das lesões parciais e completas do manguito rotador. Acta. Ortop. Bras., 8(3):144-56, 2000.

Leclear, A.; Chastang, J. F.; Niedhammer, I.; Landre, M. F. $\&$ Roquelaure, Y. Incidence of shoulder pain in repetitive work. Occup. Environ. Med., 61:39-44,2004.

Lin, T.Y.; Teixeira MJ, Romano MA, Picarelli H, Settini MM, Greve JMD’A. Distúrbios ósteo-musculares relacionados ao trabalho. Rev. Med., 80:422-42, 2001. 
Ludewig, P. M. \& Borstad, J. D. Effects of a home exercise programme on shoulder pain and functional status in construction workers. Occup. Environ. Med., 60:841-9, 2003.

Neer, I. I. C. S. Impingement lesions. Clin. Orthop., 173:707, 1983.

Novak, C. B. \& Mackinnon, S. E. Repetitive use and static postures: a source of nerve compression and pain. $J$. Hand. Ther., 10:151-9, 1997.

Plancher, K. D.; Litchfield, R. \& Hawkins, R. J. Rehabilitation of the shoulder in tennis players. Clin. Sports Med., 14:111-37, 1995.

Pope, D. P.; Silman, A. J.; Cherry, N. M.; Pritchard, C. \& Macfarlane, G. J. Association of occupational physical demands and psychosocial working environment with disabling shoulder pain. Am. Rheum. Dis., 60:852-8, 2001.

Ragasson, C. A. P. \& Stabille, S. R. Tratamento fisioterapêutico conservador em 14 pacientes portadores da síndrome da impacto do ombro. Arq. Ciênc. Saúde. Unipar, 5:171-7, 2001.

Rockwood, C. A. \& Matsen, III, F. A. Ombro. 2. ed. Rio de Janeiro, Revinter, 2002.

Sakata, R. S. \& Issey, A. M. Como diagnosticar e tratar a lesão por esforço repetitivo (LER) doença osteomuscular associada. Rev. Bras. Med., 60:77-83, 2003.

Santos, P. S. \& Filho, G. S.T. Prevalência de degeneração e ruptura do manguito rotador após a $6^{\circ}$ década de vida: análises clínico-radiográficas. Rev. Bras. Ortop., 33:6706, 1998.

Souza, T. A. General tretment approaches for shoulder disorders. In: Levingshone C, editors. Sports injuries of the shoulder-conservative management. New York, 1994. pp 487-552.

Sporrong, H.; Sandsjo, L.; Kadefors, R. \& Heberts, P. Assessment of workload and arm position during different work sequences: a study with portable devices on construction workers. Appl. Ergon., 30:495-503,1999.

Stenlund, B.; Lindbeck, L. \& Karlsson, D. Significance of house painters' work techniques on shoulder muscle strain during overhead work. Ergonomics., 45:45568,2002 .
Teixeira-Salmela, L. \& Monteiro, C. M. S. Papel do músculo bíceps braquial na estabilização da articulação glenoumeral: revisão anatômico-funcional e implicações clínicas. Rev. Fisioter. Univ. São Paulo., 1:19-29, 2001.

Tempholf, S.; Ruff, S. \& Seil, R. Age-related prevalence of rotator cuff tears in asymtomatic shoulders. J. Shoulder. Elbow. Surg., 8:296-9,1999.

Volpon, J. B.; Erdmann, K.; Nisyama, C. Y. \& Monteiro, C. R. Ruptura do manguito rotador do ombro em pacientes com pinçamento crônico. Rev. Bras. Ortop., 24:1114,1989 .

Walsh, I. A. P.; Corral, S.; Franco, R. N.; Canetti, E. E. F.; Alem, M. E. R. \& Coury, H. J. C. G. Capacidade para o trabalho em indivíduos com lesões músculo-esqueléticas crônicas. Rev. Saúde. Públ., 38(2):1-12, 2004.

Whiting, W. C.; Zernicke, R. F. Biomecânica da lesão músculo-esquelética. Rio de Janeiro, Guanabara Koogan, 2001.

\footnotetext{
Correspondence to:

Dra. Iosiane Schadeck de Almeida

22 Street, 2111-Centro Jales

CEP 15700-000

São Paulo-SP

BRASIL

Email: schaj24@hotmail.com
}

Received: 02-08-2005

Accepted: 01-10-2005 